\title{
Anaerobic Digestion of Cassava (Manihot Esculenta) Waste: Effects of Inoculum on Biogas Production Rate
}

\author{
Eboibi B. E. ${ }^{1, *}$, Adiotomre K. O. ${ }^{2}$, Onobrudu F. ${ }^{3}$ and Osioh E. ${ }^{4}$ \\ ${ }^{1,2,3,4}$ Department of Chemical and Petroleum Engineering, Faculty of Engineering, Delta State University, Oleh \\ Campus, Oleh, Delta State, Nigeria \\ Corresponding Author: *blessingeboibi@gmail.com
}

https://doi.org/10.36263/nijest.2020.02.0226

\begin{abstract}
In this paper, cow manure fluid was used as inoculums to investigate biogas production rate from anaerobic digestion of cassava peel at mesophilic temperature $\left(28^{\circ} \mathrm{C}\right)$. The anaerobic experiment was conducted using six batch digesters (D1, D2, D3, D4, D5 and D6) each of 20L capacity for 40day hydraulic retention. Each digester was loaded with $5 \mathrm{~kg}$ of cassava peel $(\mathrm{CP})$ and $0 \%, 10 \%$, $20 \%, 30 \%, 40 \%$ and $50 \%$ of inoculum to CP. Hashimoto model was used to obtain the digestion kinetic parameters. The results of the study showed that inoculums influenced the rate of biogas production, showing variations in biogas production, correlation coefficient $\left(R^{2}\right)$ and in first-order decay constant $(k)$. The average cumulative biogas production was in the range of $\sim 2358$ to $4010 \mathrm{ml} / \mathrm{kgVS}$ for $10 \%$ to $50 \%$ inoculum. The $R^{2}$ and $\mathrm{k}$ for DI was 0.959 and $0.359 \mathrm{DI}$ (without inoculum), 0.990 and 0.371 for D2 (10\% inoculum) and 0.991 and 0.371 for D3 (20\% inoculum), 0.951 and 0.356 for D4 (30\% inoculum), 0.992 and 0.372 for D5 (40\% inoculum), and 0.990 and 0.371 was obtained for D6 loaded with $50 \%$ inoculum. Despite variation in biogas yields from different inoculums, biogas production obtained from anaerobic digesters loaded with inoculums was still lower compared with that without inoculum.
\end{abstract}

Keywords: Biogas, Cassava waste, Inoculum, Bioenergy, Kinetics

\subsection{Introduction}

In the last decade, there has been increasing research on alternative energy sources to compliment fossil fuels. This has been majorly due to pollution from downstream and upstream of processing of fossil fuels, including their incessant and volatile price hikes. Biomass is one of the major sources for production of alternative energy such as biogas. The production of biogas from cassava waste, an agricultural waste has continued to attract research interest due to it availability, whereby its energy content can be exploited (Pattiya, 2011). Thomsen et al. (2014) reported cassava waste as one of the promising agricultural waste for biogas production.

Biogas, a primary product from anaerobic digestion (AD) comprises 50-70\% methane, 30-40\% carbon dioxide, and traces amounts of hydrogen sulphide and ammonia. The other product from AD is a semi-solid effluent which contains varieties of essential nutrients which is useful for plant growth and could also be applied as soil amendment. AD is a well-known technology widely used for treatment of organic waste for biogas production. The process utilizes several feedstock such as agrowaste, animal manure, municipal waste, industrial effluent, organic matter for biogas production, while simultaneously addressing agrochemical and ecological issues (Budiyono et al., 2014).

Due to the lignocellulosic nature of agricultural waste (such as cassava waste), its degradation is slow (Himmel et al., 2007). Hence, different methods have been investigated to enhance its anaerobic biodegradation (Kivaisi and Mtila, 1998; Liu et al., 2017), and consequently improving biogas yields. Some of the methods include pre-treatment, operating at thermophilic reaction temperature, and application of highly cellulolytic microorganisms (Ahring, 1995; Carrere et al., 2016; Rajput and Sheikh, 2019). These organisms are mostly sort (and referred to as inoculum or starter culture) from running anaerobic digester or prepared using animal manure using similar digestion principle. 
Review of the literature showed a number of reports on effects of inoculum prepared from cow manure on rate of biogas production from different substrates. The influence of cow manure inoculum on digestion of several substrates such as sunflower meal and wheat straw, Miscanthus Fuscus, cow manure and sludge from wastewater treatment plants have been investigated. However, there is limited information of such prepared inoculum on anaerobic digestion of cassava peel. Sunarso et al. (2010) investigated the influence of cow manure to inoculum ratio on rate of biogas production using $400 \mathrm{ml}$ biodigester at under mesophilic condition. The study showed $25-50 \%$ inoculum favours maximum biogas yields. Asante-Sackey et al. (2018) investigation was on the effect of inoculum to Miscanthus Fuscus ratio on biogas production using laboratory batch reactor at $35 \pm 2{ }^{\circ} \mathrm{C}$ under a controlled $\mathrm{pH}$. A feedstock to inoculum ratio of 3:1 was reportedly more suitable for optimum biogas yield. Also, Rajput and Sheikh, (2019) reported the impact of inoculum type and organic loading on yields of biogas from sunflower meal and wheat straw.

Moreover, the few reports on AD of cassava peel include: Aso et al. (2019) investigation using a batch mode anaerobic digestion of cassava peel. In 2011, Pattiya analyzed the proximate and ultimate analysis for cassava residues. Others investigations were on the bio-methane potential of treating cassava peel as an individual feed or codigested with organic waste using either batch or plug flow anaerobic digester (Cuzin et al., 1992; Asikong et al., 2012; Oparaku et al., 2013). These aforementioned studies have reported fundamental data on AD of cassava peel. However, there is still limited data on impact of inoculum on digestion of cassava peel. Such additional data would provide more knowledge on the biodegradability of cassava waste.

This present study is continuation of previous research investigation (Eboibi et al., 2020), where cassava peels was biologically degraded with and without a starter culture (inoculum). The previous study investigated feasibility of producing biogas from cassava peel, including impact of $10 \%$ inoculum to cassava peel on the $\mathrm{AD}$ process. To the best of our knowledge, there is limited scientific investigation on using manure fluid as inoculums in anaerobic digestion of cassava peel. The main aim of this study was to further elucidate influence of using different percentages of inoculum to substrate on the rate of degradation for anaerobic digestion of cassava peel.

\subsection{Methodology}

\subsection{Materials}

Fresh cassava peel was collected from a farmland at Oleh $\left(5.4589^{\circ} \mathrm{N}, 6.2031^{\circ} \mathrm{E}\right)$, Delta State, Nigeria. The cow manure was collected from a slaughter house at Oleh. The physiochemical properties of the cassava peel have been reported previously (Eboibi et al., 2020). AD experimental runs were carried out using a six $20 \mathrm{~L}$ anaerobic digester.

\subsection{Inoculum and feedstock preparation}

The inoculum was obtained from functional digesters, which was prepared in accordance to Budiyono et al. (2014). Briefly, the digester feedstock was prepared by mixing $3 \mathrm{~kg}$ of cow manure with nine litre (9L) of tap water. Then the mixture was loaded into the digester, followed by sealing and left to run for 14day hydraulic retention time (HRT). After complete HRT, the digester was opened, and the content was filtered using filter cloth (Budiyono et al., 2014), in order to remove the solids.

\subsection{Anaerobic digestion experimental set up.}

Six anaerobic digesters (D1, D2, D3, D4, D5 and D6) of 20L each operating capacity were operated in batch system, and simultaneously for 40day HRT under room temperature. Each experimental setup consists of a digester and biogas measuring system (water displacement method), which has also been used in previous studies (Budiyono et al., 2014; Eboibi et al., 2015; Eboibi et al., 2020). A schematic view of experimental setup has been reported previously (Eboibi et al., 2020).

The digesters were loaded with $10 \%, 20 \%, 30 \%, 40 \%$ and $50 \%$ of inoculum (IN) to cassava peel (CP). CP remains constant while water (tap water) $\left(\mathrm{H}_{2} \mathrm{O}\right)$ and inoculum varies in the digesters. Typically, and as shown in Table 1, D1 was loaded with $5 \mathrm{~kg}$ of $\mathrm{CP}, 6 \mathrm{~L}$ of $\mathrm{H}_{2} \mathrm{O}$ and no inoculum. D2 was loaded with $5 \mathrm{~kg} \mathrm{CP}, 5.5 \mathrm{~L} \mathrm{H}_{2} \mathrm{O}$, and $0.5 \mathrm{~L} \mathrm{IN}$, while D3 contains $5 \mathrm{~kg} \mathrm{CP}, 5 \mathrm{~L} \mathrm{H}_{2} \mathrm{O}$, and $1 \mathrm{~L} \mathrm{IN}$. D4, D5 and D6 were loaded with 5kg CP: 4.5L $\mathrm{H}_{2} \mathrm{O}: 1.5 \mathrm{~L} \mathrm{IN}, 5 \mathrm{~kg}$ CP:4L $\mathrm{H}_{2} \mathrm{O}: 2 \mathrm{~L} \mathrm{IN} \mathrm{and} 5 \mathrm{~kg} \mathrm{CP}: 3.5 \mathrm{~L}$ 
$\mathrm{H}_{2} \mathrm{O}: 2.5 \mathrm{~L} \mathrm{IN}$, respectively. Prior to loading the digesters, all of CP collected was homogenized and mixed with specified amounts of water and inoculum. Daily biogas yields from each digester was collected on a two-day interval basis using the water displacement method (Eboibi, 2020; Eboibi et al., 2015). Then, after attaining predefined HRT, the digester was stopped and emptied.

Table 1: List of digester loading and experimental variables

\begin{tabular}{llllll}
\hline Digester & $\begin{array}{l}\text { Cassava peel } \\
(\mathrm{CP})(\mathrm{kg})\end{array}$ & Water $(\mathrm{L})$ & Inoculum $(\mathrm{L})$ & $\begin{array}{l}\text { Room } \\
\text { temperature }\left({ }^{\circ} \mathrm{C}\right)\end{array}$ & $\begin{array}{l}\text { Hydraulic retention time, } \\
(\text { Day) }\end{array}$ \\
\hline D1 & 5 & 6 & $0(0 \%)$ & $\sim 28$ & 35 \\
D2 & 5 & 5.5 & $0.5(10 \%)$ & $\sim 28$ & 35 \\
D3 & 5 & 5 & $1(20 \%)$ & $\sim 28$ & 35 \\
D4 & 5 & 4.5 & $1.5(30 \%)$ & $\sim 28$ & 35 \\
D5 & 5 & 4 & $2(40 \%)$ & $\sim 28$ & 35 \\
D6 & 5 & 3.5 & $2.5(50 \%)$ & $\sim 28$ & 35 \\
\hline
\end{tabular}

\subsection{Yield and analysis}

The daily biogas production was collected on a two-day interval basis using water displacement method. After completion of predefined HRT, the digestion was stopped and the digestate were removed.

The cumulative yield and kinetic parameters were calculated in accordance to previous reports (Eboibi, 2020; Eboibi et al, 2020; Hashimoto, 1989). Kinetics of methane yield for each of the digester was determined using the Hashimoto, (1989) first order kinetic equation (Eq. 1). The Hashimoto equation incorporates digestion experimental parameters such as HRT, cumulative and actual methane yield, and decay constant, which helps to predict the correlation coefficient $\left(\mathrm{R}^{2}\right)$.

$B=B_{o}\left(1-\exp ^{(-k t)}\right)$

where $B$ represents the cumulative methane yield, $\mathrm{B}_{0}$, the maximum methane yield, $k$ is first order decay constant, and $t$, the hydraulic retention time.

\subsection{Results and Discussion}

\subsection{Biogas yields from digester}

Biogas production from D1 to D6 is presented in Figure 1 to Figure 6. Biogas production from mixture of $\mathrm{CP}, \mathrm{H}_{2} \mathrm{O}$, and without inoculum is shown in Figure 1. As shown in the figures, biogas production was found to be slow during the beginning and end of HRT period. This phenomenon was predicted mostly due to the fact that production of biogas under batch system corresponds to the specific growth rate of methanogenic bacteria in an anaerobic digester.

As illustrated in Figure 1, biogas production started from fifth day HRT, though 0-4day HRT were observed as the lag phase. Biogas yield was about $240 \mathrm{ml} / \mathrm{kgVS}$ at fifth day of HRT, which increased exponentially from 11day HRT and peaked at 19day HRT with maximum yield of $1155 \mathrm{ml} / \mathrm{kgVS}$. During this period, it could be assumed that there was favourable condition for microbial activities, which could have led to exponential growth of microorganism. Then, after 19day HRT, there were decrease in biogas yield, which corresponds to stationary phase. This decrease in biogas yield continued till end of experimentation, though with little fluctuations. The minimum yield $100 \mathrm{ml} / \mathrm{kgVS}$ was at the at last day of HRT. The decrease in biogas yields obtained towards end of HRT could be due to decrease in microbial activities. 


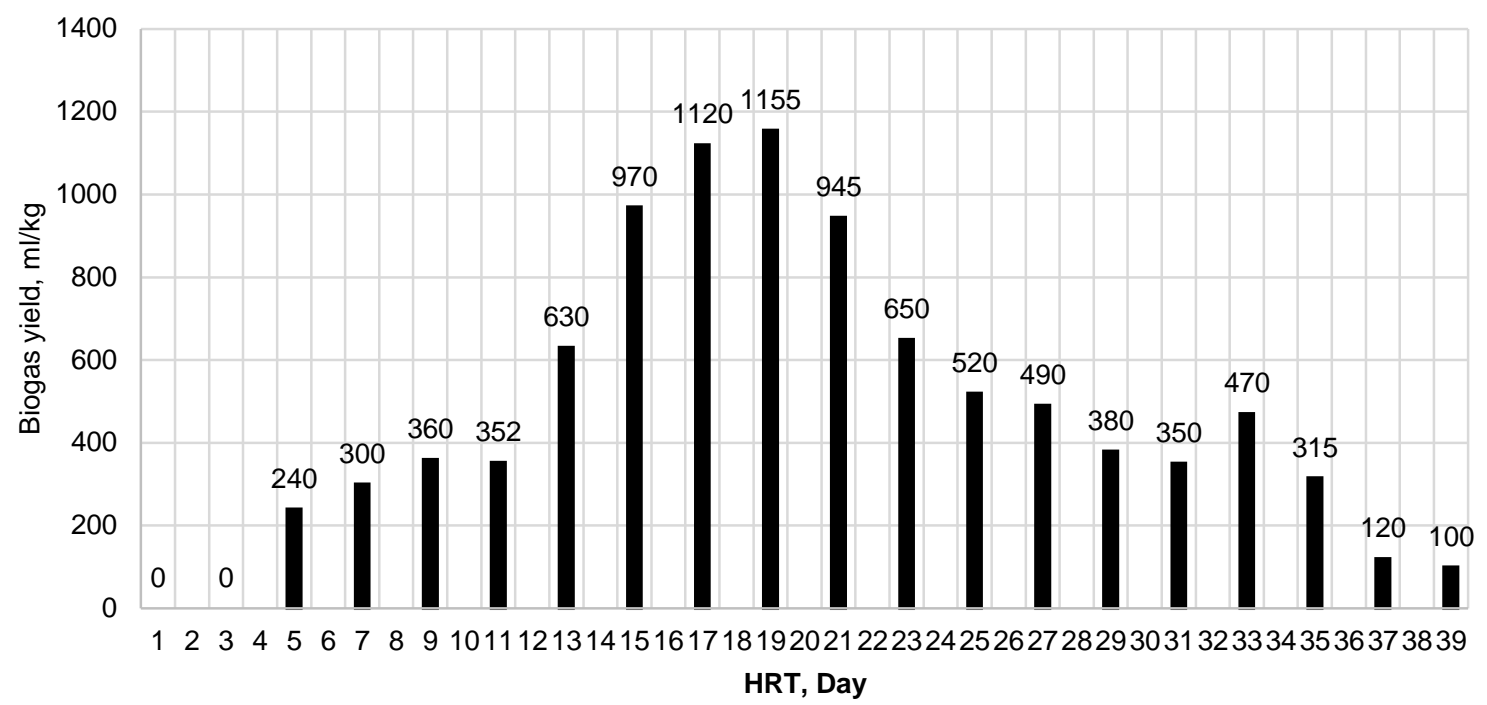

Figure 1: Biogas yield from anaerobic digestion of cassava peel without inoculum

The biogas yield obtained from D2 loaded with $10 \%$ inoculum to CP is presented in Figure 2. It is clear from Figure 2 that the trend of biogas production was similar to that of D2, though, the amounts of biogas yield differs. As shown in Figure 2, there were no substantial impact of adding $10 \%$ inoculum to digestion of $\mathrm{CP}$. Although, there are limited report on influence of inoculum on biodegradation of cassava waste, Lopez et al. (2004) reported similar finding where 5\% to $10 \%$ inoculum had no substantial effects on degradation of municipal solid waste.

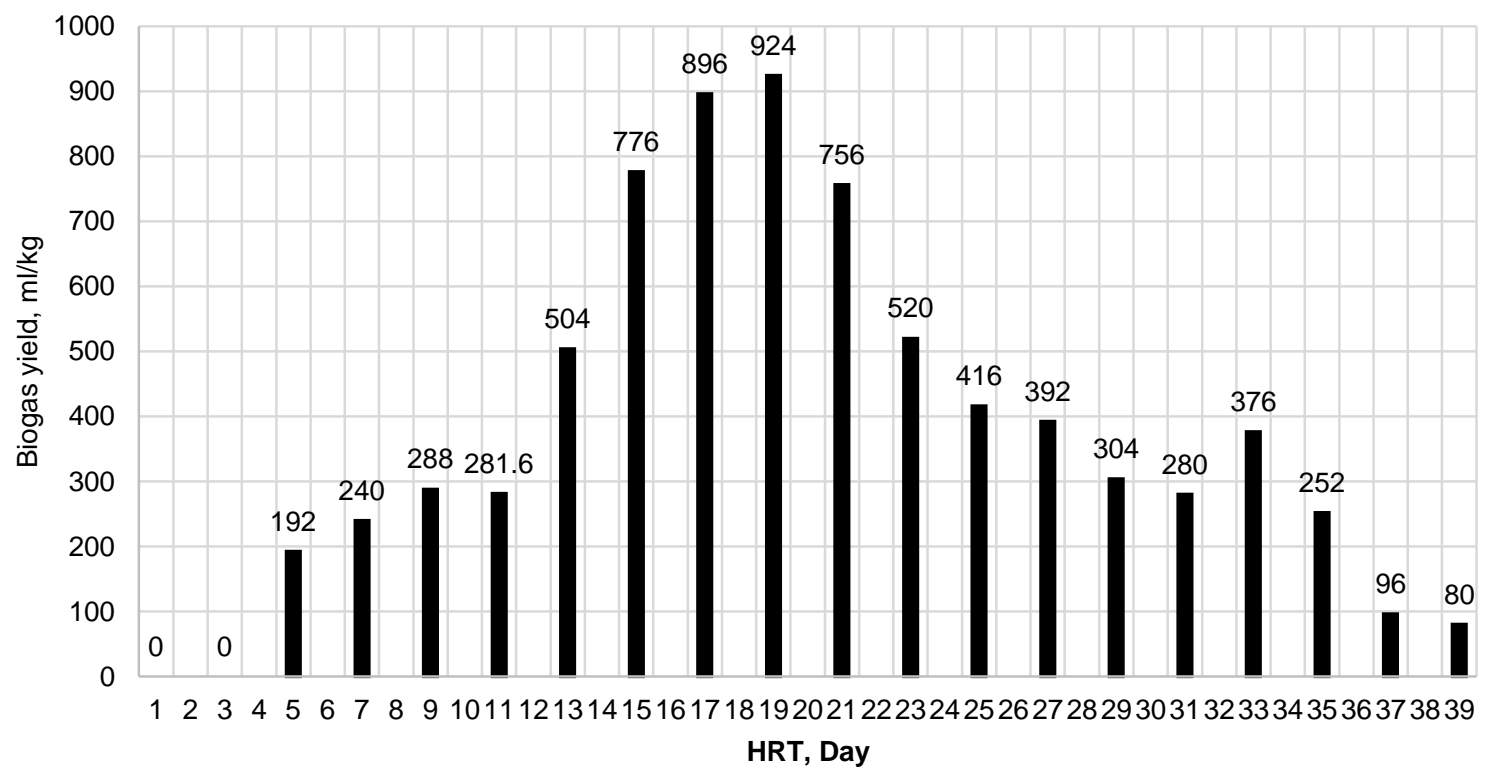

Figure 2: Biogas yield from AD of cassava peel with $10 \%$ inoculum

In the present study, maximum biogas yield of $924 \mathrm{ml} / \mathrm{kgVS}$ was obtained at $19 \mathrm{day} \mathrm{HRT}$, same period where D1 had its maximum yield of $1155 \mathrm{ml} / \mathrm{kgVS}$. However, D3 which was loaded with $20 \%$ inoculum were found to enhanced digestion time, as shown in Figure 3. Although, D3 had similar trend as observed for previous digesters, its maximum yield of $\sim 900 \mathrm{ml} / \mathrm{kgVS}$ was obtained at 17 day HRT, which was two days HRT earlier when compared to D2 and D1. Although, the average yield of biogas from D3 ( 373 ml $/ \mathrm{kgVS})$ were marginally lower than D2 $(\sim 378 \mathrm{ml} / \mathrm{kgVS})$, the rate of biogas production at the beginning and end of HRT period were more when compared to previous digesters. This finding suggests that $20 \%$ inoculum had more substantial effects on the rate of degradation of cassava peel. 


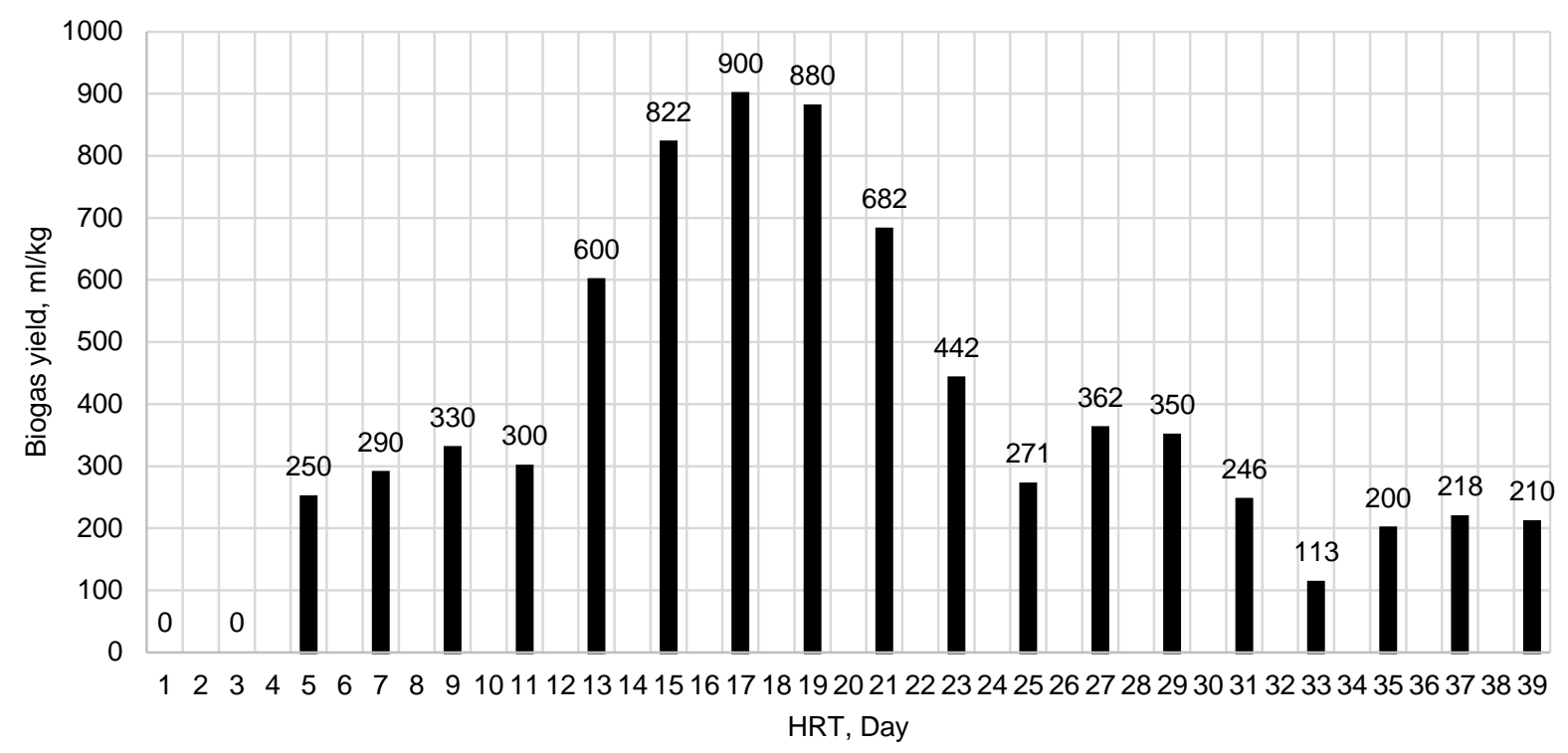

Figure 3: Biogas yield from AD of cassava peel with $20 \%$ inoculum

Furthermore, the biogas yields from digester 4 (D4) of $30 \%$ inoculum is presented in Figure 4. As illustrated in the figure, the trend in biogas yield was very different compared to previous digesters, and it was characterised with low yields when compared to D1 to D3. The maximum yield of $575 \mathrm{ml} / \mathrm{kgVS}$ obtained at 17 day HRT was the only similar feature when compared to D3, which had its maximum yield at 17 dayHRT.

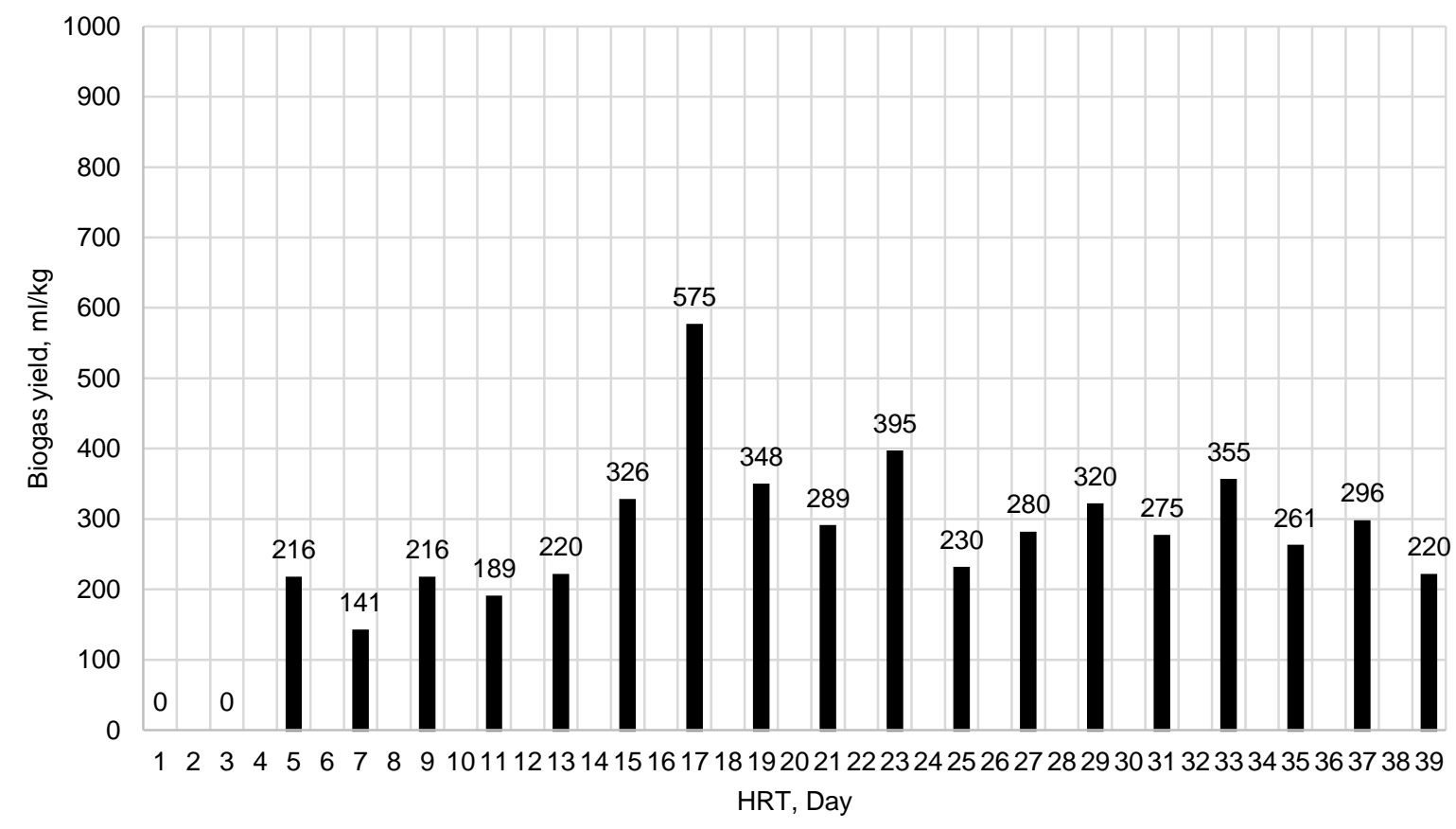

Figure 4: Biogas yield from $\mathrm{AD}$ of cassava peel with $30 \%$ inoculum

Besides that, D3 was found to have performed poorly in terms of biogas production, with the lowest average biogas yield of approximately $286 \mathrm{ml} / \mathrm{kgVS}$. This suggests $30 \%$ inoculum had inhibitory effects on the overall digestion process, hence low degradation of substrate.

Figure 5 showed the biogas yield from D5. The average biogas yield of was about $17.8 \%$ higher than that from D5. but still lower than average yields of $\sim 474 \mathrm{ml} / \mathrm{kgVS}$ for D1, $\sim 378 \mathrm{ml} / \mathrm{kgVS}$ for D2 and $373 \mathrm{ml} / \mathrm{kgVS}$ for D3. Also, the maximum yield for biogas yield for previous digesters have been either at 17 day HRT or 19dayHRT, but for D5 it shifted to 21 day HRT with $456 \mathrm{ml} / \mathrm{kgVS}$ biogas yield. The rate of biogas production towards the end of HRT was higher compared to previous digesters. 


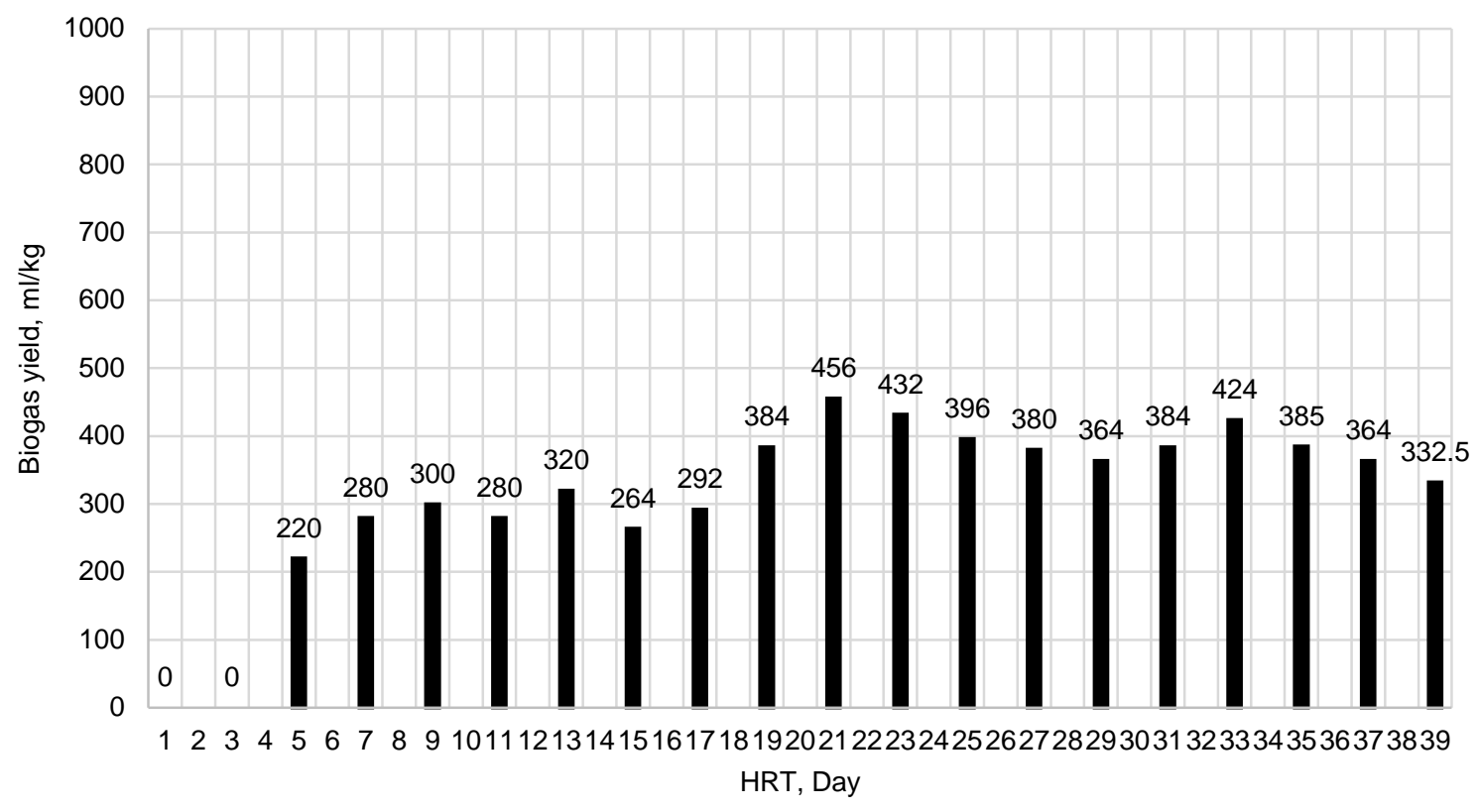

Figure 5: Biogas yield from AD of cassava peel with $40 \%$ inoculum

Biogas yield from AD of cassava peel with $50 \%$ inoculums is presented in Figure 6. Similar to attainment of maximum biogas yield at 21day HRT for D5, D6 had its maximum biogas yield of $570 \mathrm{ml} / \mathrm{kgVS}$ at 21day HRT. The rate of biogas production was found to be higher at the initial and final stages of digestion. As shown in Figure 6 and Figure 5, D6 and D5 (that is 50\% and 40\% inoculum), after 49day HRT, still had the tendency for increase production of biogas, as the yields were still high. This finding suggests that the $40 \%$ and 50\% inoculums prepared from cow manure were dominated with high concentration of celluloytic bacteria capable in degrading the cellulose component of $\mathrm{CP}$. This reaffirms that rate of degradation varies with digesters, as anaerobic bacteria differ in each digester hence variation in biogas yields. Also, carbon content of organic waste may not be equally degraded to biogas via AD (Budiyono et al., 2014), as lignin content do prevent or lower biodegradability of organic matter. This finding suggests that addition of 50\% inoculum to $\mathrm{CP}$, were more suitable for enhanced degradation of $\mathrm{CP}$ when compared to $10 \%$ to $40 \%$ inoculums addition.

Despite improved biogas yields from D6; its average yield was about 7\% lower when compared to digestion of CP alone. Nevertheless, this study has shown that $50 \%$ inoculum could be suitable to improved degradation of cassava peel. However, it could not be ascertained that $50 \%$ is the optimum condition, because the study did not investigate use of inoculums of more than $50 \%$. 


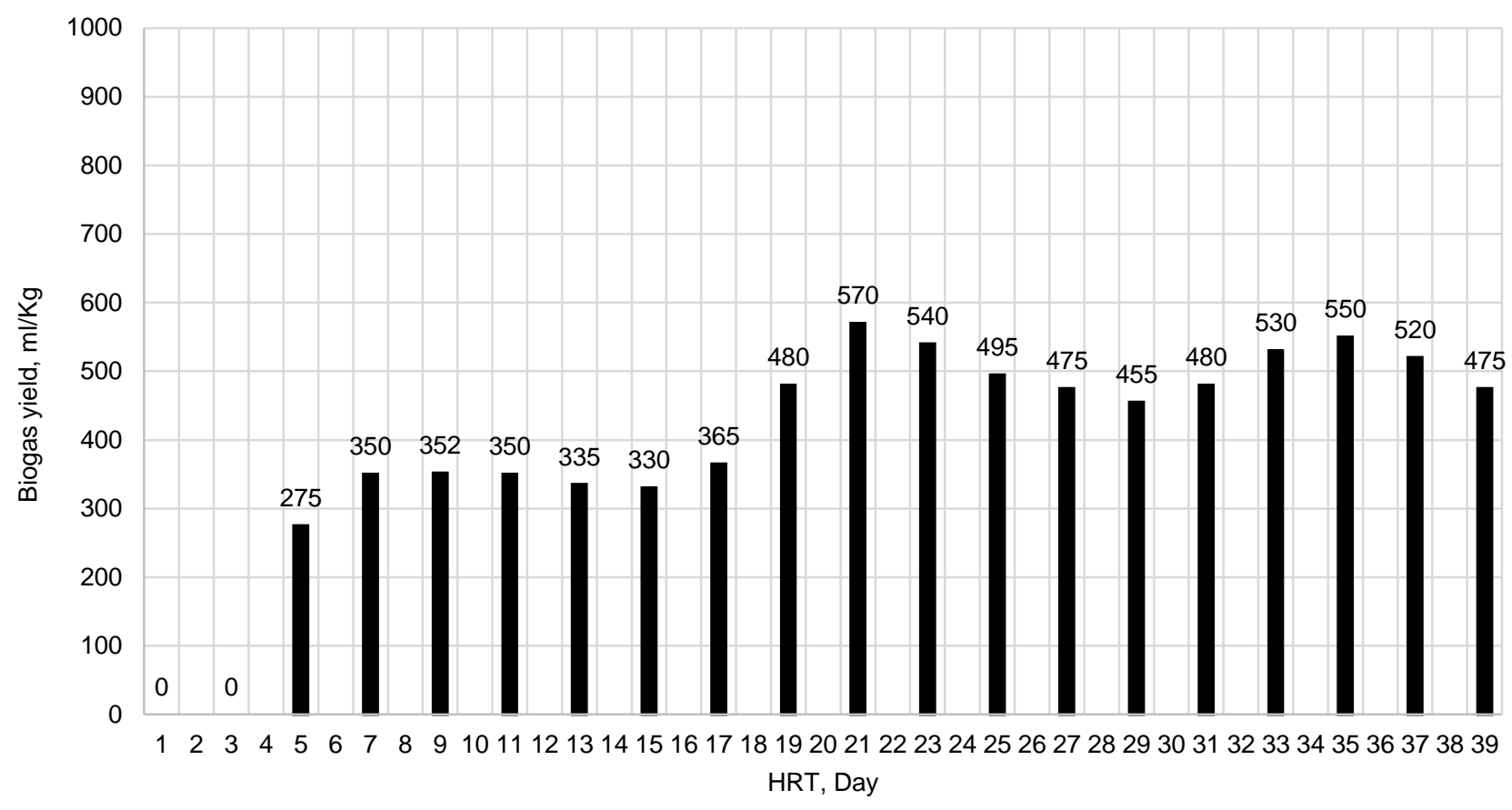

Figure 6: Biogas yield from AD of cassava peel with 50\% inoculums

\subsection{Cumulative biogas yields and kinetic parameters}

The profiles of cumulative biogas yield from different digesters are shown in Figure 7, while the obtained kinetic parameters are presented in Table 2. The rate of biogas production from CP and using $10 \%$ inoculum tends to obey sigmoid function, as normally observed in batch growth curve (Budiyono et al., 2014). Figure 7 shows that cumulative biogas production varies with \% inoculums. The average cumulative biogas yield was in the range of $\sim 2358$ to $4010 \mathrm{ml} / \mathrm{kgVS}$ for $10 \%$ to $50 \%$ inoculum compared to $4906 \mathrm{ml} / \mathrm{kgVS}$ of cassava peel. Beside cumulative yield for $\mathrm{CP}$, maximum cumulative biogas yield was observed for $30 \%$ inoculum resulting in $4010 \mathrm{ml} / \mathrm{kgVS}$. Similar to this finding, Forster-Carneiro et al. (2008) reported 30\% as optimum inoculum for biodegradation of food waste using 1.1L capacity anaerobic batch reactor. Also, it could be deduced from Figure 7, that biogas production rate was slow at initial and final period of experimentation. This is majorly due to the fact that production of biogas under batch condition directly corresponds to specific growth rate of methanogenic bacteria in anaerobic digester, as mentioned previously. 


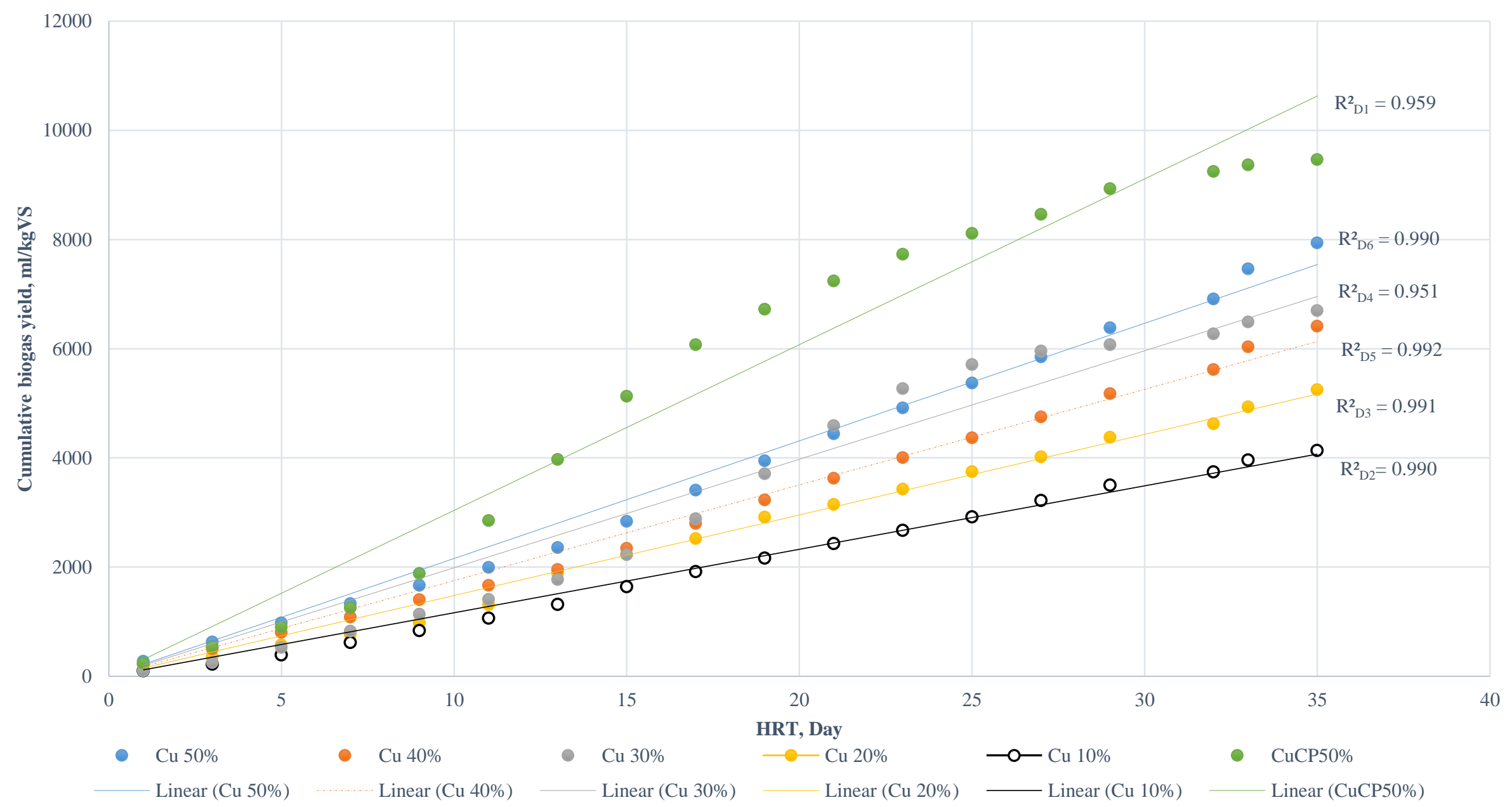

Figure 7: Cumulative biogas yield from AD of cassava with different percentages of inoculum 
Table 2: Comparison of kinetic parameters of present study with those of previous studies

\begin{tabular}{lllll}
\hline Organic waste & Digester & $R^{2}$ & $k$ & References \\
\hline Cassava peel & D1 & 0.959 & 0.359 & Present study \\
& D2 & 0.990 & 0.371 & Present study \\
& D3 & 0.991 & 0.371 & Present study \\
& D4 & 0.951 & 0.356 & Present study \\
& D5 & 0.992 & 0.372 & Present study \\
Cassava peel & D6 & 0.990 & 0.371 & Present study \\
Food waste & - & $0.91-0.96$ & $0.06-0.36$ & Eboibi et al., (2020) \\
Rice straw & - & $0.86-0.99$ & $0.056-0.364$ & Browne and Murphy, (2013) \\
Wheat & - & 0.980 & 0.15 & Li et al., (2013) \\
\hline
\end{tabular}

\subsection{Conclusions}

Reduction of solid waste mass is one of the principal objectives of anaerobic digestion. This present study investigated the feasibility to improve anaerobic digestion of cassava waste, for enhance biogas production. Although, the data obtained showed influence of varying inoculum (10\% to $50 \%)$ on digestion, but with lower biogas yields when compared to that from anaerobic treatment of cassava peel without inoculum. AD of cassava peel $(\mathrm{CP})$ without inoculum had a maximum cumulative yield of $4906 \mathrm{ml} / \mathrm{kgVS}$ followed by $4010 \mathrm{ml} / \mathrm{kgVS}$ from treatment of CP with $30 \%$ inoculum.

\section{References}

Ahring, B. K. (1995). Methanogenesis in thermophilic biogas reactors. Antonie van Leeuwenhoek, 67, pp. 91-102.

Asante-Sackey, D., Tetteh. E. K., Nkosi. N., Boakye, G. O., Ansah. A. K. O., et al. (2018). Effects of inoculum to feedstock ratio on anaerobic digestion for biogas production. Int'l Journal of Hydrology, 2(5), pp. 567-571.

Aso, S. N., Pullammanappallil, P. C., Teixeira. A. A. and Welta, B. A. (2019) Biogasification of cassava residue for on-site biofuel generation for food production with potential cost minimization, health and environmental safety dividends. Environmental Progress \& Sustainable Energy, DOI 10.1002/ep.

Asikong, B. E., Epoke, J., Agbo, B. E., Antai, E. E. and Eja, M. E. (2013). Potentials of biogas generation from mixture of three substrates, water hyacinth, cassava peels and cow dung$\mathrm{Wh}+\mathrm{Cp}+\mathrm{Cd}$, Chemical and Process Engineering Research, 17, pp. 1-12.

Browne, J. D. and Murphy, J. D. (2013). Assessment of the resource associated with biomethane from food waste. Applied Energy, 104, pp. 170-177.

Budiyono, B., Widiasa, I. N., Johari, S. and Sunarso, S. (2014). Increasing biogas production rate from cattle manure using rumen fluid as inoculums. Int'l Journal of Science and Technology, 6, pp. $31-38$

Carrere, H., Antonopoulou, G., Affes, R., Passos, F., Battimelli, A., Lyberatos, G. amd Ferrer, I. (2016). Review of feedstock pretreatment strategies for improved anaerobic digestion: from lab-scale research to full-scale application. Bioresour. Technol., 199, pp. 386-397.

Cuzin, N., Farinet, J. L., Segretain, C., Labat, M. (1992). Methanogenic fermentation of cassava peel using a pilot plug flow digester. Bioresource Technol., 41, pp. 259-264.

Eboibi, B. E. (2020). Anaerobic digestion of cow manure: influence of hydraulic retention time on biogas yield and properties of digestate. Lautech Journal of Engineering and Technology, 14(1), pp. 87-97.

Eboibi, B. E., Atikpo, E., Ihueghian, P, and Ogiribo, P. (2020). Characteristics of products from anaerobic digestion of cassava waste for biogas production. Journal of Experimental Research, 8, pp. $36-44$ 
Eboibi, B. E., Lewis, D. M., Ashman, P. J. and Chinnasamy, S. (2015). Integrating anaerobic digestion and hydrothermal liquefaction for renewable energy production: An experimental investigation. Environmental Progress \& Sustainable Energy, 34, pp. 1662-1673.'

Hashimoto, A. G. (1989). Effect of inoculum substrate ratio on methane yield and production rate from straw. Biological Wastes, 28, pp. 247-255.

Forster-Carneiro, T., Pe'rez, M. and Romero, L. I. (2008). Influence of total solid and inoculum contents on performance of anaerobic reactors treating food waste. Bioresource Technology, 99, pp. 6994-7002.

Himmel, M. E., Ding, S. Y., Johnson, D. K., Adney, W. S., Nimlos, M. R., Brady, J. W. and Foust, T. D. (2007). Biomass recalcitrance: engineering plants and enzymes for biofuels production. Science, 315 , pp. 804-7

Kivaisi, A. K. and Mtila, M. (1998). Production of biogas from water hyacinth (Eichhornia crassipes) (Mart) (Solms) in a two-stage bioreactor. World Journal of Microbiology \& Biotechnology, 14, pp. 125-131.

Li, Y., Zhang, R., Liu, G., Chen, C., He, Y. and Liu, X. (2013). Comparison of methane production potential biodegradability, and kinetics of different organic substrates. Bioresource Technol., 149, pp. $565-569$.

Liu, T., Sun, L., Müller, B. and Schnürer, A. (2017). Importance of inoculum source and initial community structure for biogas production from agricultural substrates. Bioresource Technol., 245, pp. 768-777.

Lopez, W. S., Leite, V. D. and Prasad, S. (2004). Influence of inoculum on performance of anaerobic reactors for treating municipal solid waste. Bioresource Technol., 94, pp. 261-266.

Oparaku, N. F., Ofomatah, A. C. and Okoroigwe, E. C. (2013). Biodigestion of cassava peels blended with pig dung for methane generation. African Journal of Biotechnology, 12, pp. 5956-5961.

Pattiya, A. (2011) Thermochemical Characterization of Agricultural Wastes from Thai Cassava Plantations. Energy Sources, Part A: Recovery, Utilization, and Environmental Effects, 33 (8), pp. 691-701.

Rajput, A. A., and Sheikh, Z. (2019). Effect of inoculum type and organic loading on biogas production of sunflower meal and wheat straw. Sustainable Environment Research, 29:4. https://doi.org/10.1186/s42834-019-0003-x.

Sunarso, S., Johari, I. N., Widias, and Budiyono (2010). The effect of feed to inoculums ratio on biogas production rate from cattle manure using rumen fluid as inoculums. Int'l. J. of Sci. and Eng.1(2), pp. 41-45.

Thomsen, S.T., Kadar, Z. and Schmidt, J.E. (2014). Compositional analysis and projected biofuel potentials from common West African agricultural residues. Biomass and Bioenergy, 63, pp. 210-217.

Cite this article as:

Eboibi B. E., Adiotomre K. O., Onobrudu F. and Osioh E., 2020. Anaerobic Digestion of Cassava (Manihot Esculenta) Waste: Effects of Inoculum on Biogas Production Rate. Nigerian Journal of Environmental Sciences and Technology, 4(2), pp. 411-420. https://doi.org/10.36263/nijest.2020.02.0226 